\title{
Application of Geographically Weighted Regression for Vulnerable Area Mapping of Leptospirosis in Bantul District
}

\author{
Prima Widayani, Totok Gunawan, Projo Danoedoro and Sugeng Juwono Mardihusodo
}

Received: 032 2016 / Accepted: 0506 2016 / Published online: 30122016

C 2016 Faculty of Geography UGM and The Indonesian Geographers Association

\begin{abstract}
Geographically Weighted Regression (GWR) is regression model that developed for data modeling with continuous respond variable and considering the spatial or location aspect. Leptospirosis case happened in some regions in Indonesia, including in Bantul District, Special Region of Yogyakarta. The purpose of this study are to determine local and global variable in making vulnerable area model of Leptospirosis disease, determine the best type of weighting function and make vulnerable area map of Leptospirosis. Alos satelite imagery as primary data to get settlement and paddy fields area. The others variable are the percentage of population's age, flood risk, and the number of health facility that obtained from secondary data. Determinant variables that affect locally are flood risk, health facility, percentage of age 25-50 years old and the percentage of settlement area. Meanwhile, independent variable that affects globally is the percentage of paddy fields area. Vulnerability map of Leptospirosis disease resulted from the best GWR model which used weighting function Fixed Bisquare. There are 3 vulnerable area of Leptospirosis disease, high vulnerability area located in the middle of Bantul District, meanwhile the medium and low vulnerability area showed clustered pattern in the side of Bantul District.
\end{abstract}

Keywords: Geographically Weighted Regression, Leptospirosis, Vulnerability

Abstrak Geographically Weighted Regression (GWR) adalah model regresi yang dikembangkan untuk memodelkan data dengan variabel respon yang bersifat kontinu dan mempertimbangkan aspek spasial atau lokasi. Kejadian Leptospirosis terjadi di beberapa wilayah di Indonesia termasuk di wilayah Kabupaten Bantul Daerah Istimewa Yogyakarta. Tujuan dari penelitian ini adalah menentukan variabel lokal dan global dalam membuat model kerentanan Leptospirosis dan menentukan jenis fungsi pembobot yang terbaik serta membuat peta kerentanan wilayah Leptospirosis menggunakan aplikasi GWR. Citra Satelit Alos digunakan untuk mendapatkan data penggunaan lahan, yang selanjutnya diturunkan menjadi prosentase luas permukiman dan sawah. Parameter lainya adalah prosentase umur penduduk, resiko banjir dan jumlah fasilitas kesehatan yang diperoleh dari data sekunder. Variabel yang berpengaruh secara lokal adalah Risiko Banjir, Fasilitas Kesehatan Presentase Usia 25-50 tahun, Prosentase Luas Pemukiman, sedangkan variabel independen yang bepengaruh secara global adalah Presentase Luas Sawah. Peta kerentanan Leptospirosis yang dihasilkan dari model GWR terbaik yaitu menggunakan fungsi pembobot Fixed Bisquare. Terdapat 3 kelas kerentanan Leptospirosis yaitu kelas kerentanan tinggi berada di desa-desa di tengah Kabupaten Bantul, sedangkan kelas sedang dan rendah menunjukkan pola menggelompok di wilayah pinggiran Kabupaten Bantul

Kata kunci: Geographically Weighted Regression, Leptospirosis, Kerentanan

\section{Introduction}

Geographically Weighted Regression (GWR) is regression model that developed for data modeling with continuous respond variable and considering the spatial or location aspect. Spatial data have geographical reference (geographic coordinate). Linear regression method is not suitable for spatial

Prima Widayani, Totok Gunawan, Projo Danoedoro and Sugeng Juwono Mardihusodo

Faculty of Geography, Universitas Gadjah Mada, Indonesia

Email: primawidayani@ugm.ac.id data modeling because it ignores the location aspect. One of the methods for spatial data modeling is GWR. GWR model is developed from global regression model based on non-parameteric regression. Estimation parameter of GWR model used Least Square that given coordinates of location as weighting factor [Yoeniarti, 2008]. The use of GWR is needed for spatial modeling, one of them is a modeling that related to environmental health.

Mapping in health field is growing along with many disease that spreading in society and determined by environmental factors. Vulnerability 
mapping is done to obtained spatial overview of area that potentially affect based on its environment condition. Disease epidemiologically determined by 3 primary factors, they are agent factor of disease which related to the cause including the number, virulence, and pathogenicity of leptospira bactery. Second factor is the factors that related to host factor [the patient] include in it are individual hygiene, nutritional status, age and education level. Third factor is environment, including physical, biological, social-economy and cultural environment.

Leptospirosis case many occured in Tropic area. Leptospirosis also left some public health problem on several continents as Asia, East and South Europe, Australia and New Zealand. Report from USA said that the number of patients or Leptospirosis case to human is $50-150$ person/ year. In Indonesia, Leptospirosis case spread in West Java, Central Java, Special region of Yogyakarta, Lampung, South Sumatera, Bengkulu, Riau, West Sumatera, North Sumatera, Bali, NTB, South Sulawesi, North Sulawesi, East Kalimantan and West Kalimantan [Widarso in Priyanto, 2008]. This epidemic disease within a few years had infected residents in Bantul District, from 2009 to 2014 there are already \pm 468 case (Highest rate located in Bantul, Imogiri, Jetis and Sedayu districts). Based on this fact, vulnerable area mapping of Leptospirosis disease is needed to determine handling and prevention priority areas.

Geographically Weighted Regression (GWR) first introduced by Fotherinham in 1967. GWR model is development of classic linear regression or Ordinary Linear Reggresion (OLR). GWR model is regression model that developed for data modeling with continuous respond variable and considering the spatial aspect. Model of GWR is as follows :

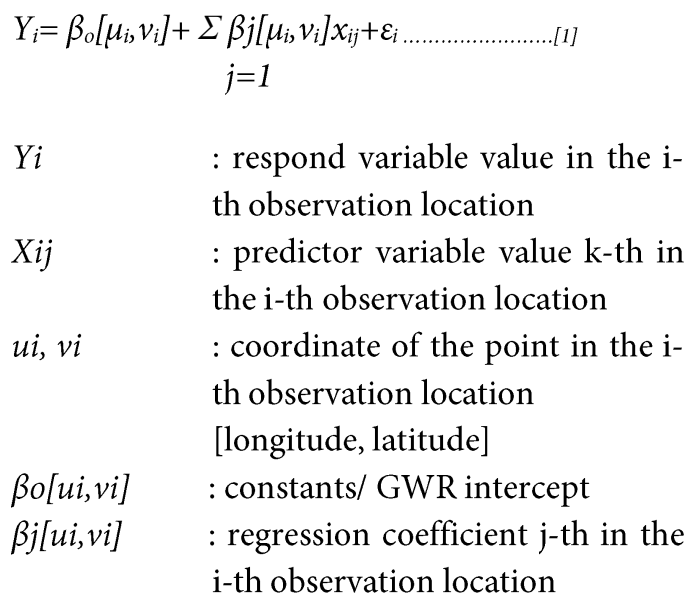

$\varepsilon i$

\author{
: error in the $\mathrm{i}$-th observation \\ location which assumed \\ independent, identical and in \\ normal distribution with average \\ value 0 and varians $\sigma^{2}$ \\ [Fotherinham, 2002].
}

Geographically Weighted Regression (GWR) is one of methods that effective enough to estimate data which have spatial heterogeneity [Fotheringham, 2002]. Basic idea of GWR is that parameter can be calculated anywhere in study area with dependent variable and one or more independent variable that measured in some places whose location are known [Fotheringham, 2002]. Based on dependent variable distribution, GWR consist of 3 types, they are gaussian model, poisson model, and logistic model. Gaussian model is used if the dependent variable are continuous data. Poisson model or usually called with Geographically Weighted Poisson Regression (GWPR) is used if the dependent variable consist of number with positive integer value. Meanwhile, logistic model or usually called with Geographically Weighted Logistic Regression (GWLR) is used if the dependent variable are categorical scale data, nominal or ordinal.

Leptospirosis is a disease which can be transmitted from animal to human. It is caused by aerob bactery leptospira (group of spirochaeta) in spiral form and move actively. Leptospirosis is acute infectious disease that affects human and animal which is caused by leprospira pathogen bactery and classified as zoonosis. Leptospira.sp bactery can live within animal body such as rat, pig, and dog. In the rat's body, this bactery live within its kidney and exit through its urine. Rat urine can be everywhere and carried away by rain, river, flood and also can be found in trashes [Riyaningsih, et al., 2010]. Leptospira bactery can enter into human's body through some medias, such as :

a. Can enter into the eyes through splashes of water that already contaminated by Leptospira bactery or contacted with rat urine.

b. Can enter into human's body through food or beverages that already contaminated by rat urine or water with Leptospira bactery.

c. Can enter into human's body though skin that opened because of scar or blister which contacted with water that already contamined by Leptospira bactery. 
Based on research done by Priyanto [2008], risk factors that had proven gave effect on Leptospirosis case are : bad gutter condition, existance of trash in the house, existance of rats in or surrond the house, habbit of not wearing any footwear, habbit of take a bath/wash in the river, health-risked job and there is no counseling about Leptospirosis.

ALOS is the biggest satelite which developed and launched by JAXA's Tanegashima Space Center Japan in Januari, $24^{\text {th }} 2006$ using H-IIA rocket. It is designed to operate for 3-5 years, while carry 3 sensor, they are Panchromatic Remote Sensing Instrument for Stereo Mapping (PRISM) with 2,5 meter spatial resolution, Advanced Visible and Near Infrared Radiometer type-2 (AVNIR-2) with 10 meter spatial resolution and Phased Array type L-band Synthetic Aperture Radar (PALSAR) with 10 meter and 100 meter spatial resolution. Revisiting period of ALOS satelite is 46 days, but for disaster monitoring or emergency situation, ALOS can observe in 2 days [NSDA, 2009].

Development of remote sensing technology also balanced by Geographic Information System (GIS) development. GIS can be used for public health program and epidemiological data such as health facility mapping (public health office, hospital, puskesmas, pustu and polindes), distribution of Leptospirosis case and endemic area mapping. This information will be useful for disease spreading risk mapping, identify pattern and distribution of disease, also estimate the spread and countermeasures of disease. One of the purposes from this disease mapping are :

a. Describe distribution of the disease geographically

b. Identify area with high disease risk so it can be used as basic act of disease transmission prevention.

c. The right regional resource management for increasing halth status in some region.

Vulnerability is a condition where some community or society that lead or cause inabililty to facing the danger. Vulnerability is a condition which can decrease public ability to prepare and face the danger ; general condition including physical, social-economy, political and cultural factors which potentially cause a group of society more easily affected by disaster, or hamper public ability to do some acts toward disaster.

This study aims to (1) determine local and global variable in making vulnerable area model of
Leptospirosis disease and determine type of the best weighting function. (2) Mapping vulnerability area of Leptospirosis in Bantul District.

\section{The Methods}

This study use ALOS satelite imagery for obtain land use data. Land use data then formulated to percentage of settlement and paddy fields area in each village. Another data needed for this study are population's age, number of health facility, and flood risk. Leptospirosis case data in each village which obtained from Public Health Office of Bantul District are used as dependent variable, meanwhile the percentage of settlement and paddy fields area in each village, population's age, number of health facility, and flood risk are used as independent variables.

Tools used in this study are a set of PC/AT P-4 $3200 \mathrm{MHz}$ computer, $2 \mathrm{MB}$ RAM, 80 GB HD, high resolution colored-monitor 17 ' for data processing dan report writing. GWR 4 software used for data processing with Geographically Weighted Regression method, and also Arc GIS 10.2 software for make the map. With the help of GIS data analysis process can be done digitally in faster and better ways with relatively greater data storage capacity compared to manual data [Harini, et al., 2015]. Printer used for imagery and thematic maps printing, and fieldsurvey equipments (GPS and camera).

Steps of analysis in this study are: (1) Testing GWR model assumptions; (2) Assessment of the effect of spatial; (3) Calculate the Euclidean distance between point locations; (4) Determine the optimum bandwidth; (5) Calculated by entering the weighting matrix of Euclidean distances and optimum bandwidth; (6) Estimation of parameters using WLS; (7) Testing of the model parameters simultaneously and partially GWR; (8) Testing suitability GWR models using the coefficient of determination. Figure 1.1. shows the steps of modeling in software GWR 4 . 


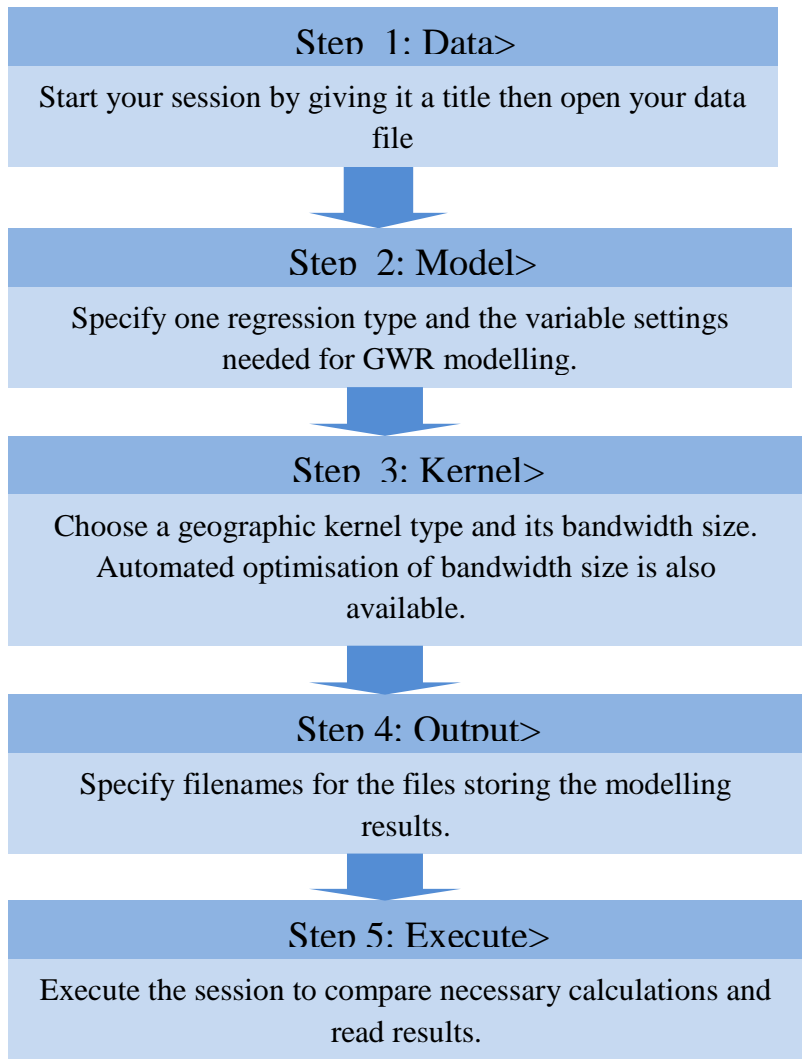

Figure 1.1. Step in GWR Modelling Sesion with Respect to The Five Tabs [Nakaya, 2009]

\section{Result and Discussion}

Basically independent variables should be uncorrelate in Geographically Weighted Regression, its needs be tested by multicolinearity test. Statistical tests were perfomed by Pearson Correlation and Variance Inflation Factors (VIF). There are five independent variables; flood risk (X1), health facility (X2), percentage of age 25-50 years old (X3) and the percentage of settlement area (X4). Meanwhile, independent variable that affects globally is the percentage of paddy fields area (X5). Meanwhile, case of Leptospirosis of 2009 - 2011 used to be dependent variable. Table 1.1. shows result of Pearson Correlation test. Number of Sig. (2 tailed) more than 0,005 shows that there are is no correlate between variables.

The table 1.1. stated that there aren't number of Sig. (2 tailed) that lower than 0,005 , so we can conclude that variables uncorrelate each others. Further, examine variables use multicolinearity test conducted by SPSS. Table 1.2. Show about theresult of multicolinearity test that indicated by number of
VIF.

Number of VIF that lower than ten shows that there isn't multicolinearity at the variables. It can clearly seen in the table 1.2. number of VIF each variables are around one, so it can be conclude that there aren't multicolinearity.

Before modelling spatial regression semiparametric, variables assesment of GWR model performed to get local and global variables which are appropriate with the model. According to significance test in every observation location if using level of significance $[\alpha] 10 \%$ so the number of $z_{\left({ }^{\circ} / 10\right)}$ is 1,64 . Table 1.3. below shows the result of significance test that performed by GWR 4.0 software. Result from that software helps to choose best model which can be used. Best model indicated by lowest number of AIC, therefore Fixed Bisquare Kernel is the best model. Furthermore, this kernel has the lowest number AIC with 367,10. Result of modelling with Fixed Bisquare kernel can be seen in Tabel 1.4. 
Table 1.1. Result of Multicriteria Test for Variable

\begin{tabular}{|c|c|c|c|c|c|c|c|}
\hline & & $\begin{array}{l}\text { Flood } \\
\text { Risk }\end{array}$ & $\begin{array}{c}\text { Health } \\
\text { Facilities }\end{array}$ & Age & $\begin{array}{c}\text { Case of } \\
\text { Leptospirosis }\end{array}$ & $\begin{array}{c}\text { Percentage } \\
\text { of } \\
\text { Settlement }\end{array}$ & $\begin{array}{c}\text { Precentage } \\
\text { of Paddy } \\
\text { Field }\end{array}$ \\
\hline \multirow[t]{4}{*}{ Flood Risk } & Pearson & 1 & .184 & .217 & .029 & -.071 & $.266^{*}$ \\
\hline & Correlation & & & & & & \\
\hline & Sig. [2-tailed] & & .114 & .061 & .805 & .547 & .021 \\
\hline & $\mathrm{N}$ & 75 & 75 & 75 & 75 & 75 & 75 \\
\hline Health & Pearson & .184 & 1 & .059 & .113 & $.307^{* *}$ & .106 \\
\hline \multirow[t]{3}{*}{ Facilities } & Correlation & & & & & & \\
\hline & Sig. [2-tailed] & .114 & & .615 & .336 & .007 & .367 \\
\hline & $\mathrm{N}$ & 75 & 75 & 75 & 75 & 75 & 75 \\
\hline \multirow[t]{4}{*}{ Age } & Pearson & .217 & .059 & 1 & -.009 & .019 & .103 \\
\hline & Correlation & & & & & & \\
\hline & Sig. [2-tailed] & .061 & .615 & & .940 & .869 & .381 \\
\hline & $\mathrm{N}$ & 75 & 75 & 75 & 75 & 75 & 75 \\
\hline Case of & Pearson & .029 & .113 & -.009 & 1 & .147 & $.323^{* *}$ \\
\hline \multirow[t]{3}{*}{ Leptospirosis } & Correlation & & & & & & \\
\hline & Sig. [2-tailed] & .805 & .336 & .940 & & .208 & .005 \\
\hline & $\mathrm{N}$ & 75 & 75 & 75 & 75 & 75 & 75 \\
\hline Percentage of & Pearson & -.071 & $.307^{* *}$ & .019 & .147 & 1 & .093 \\
\hline \multirow[t]{3}{*}{ Settlement } & Correlation & & & & & & \\
\hline & Sig. [2-tailed] & .547 & .007 & .869 & .208 & & .426 \\
\hline & $\mathrm{N}$ & 75 & 75 & 75 & 75 & 75 & 75 \\
\hline \multirow{4}{*}{$\begin{array}{l}\text { Precentage of } \\
\text { Paddy Field }\end{array}$} & Pearson & $.266^{*}$ & .106 & .103 & $.323^{* *}$ & .093 & 1 \\
\hline & Correlation & & & & & & \\
\hline & Sig. [2-tailed] & .021 & .367 & .381 & .005 & .426 & \\
\hline & $\mathrm{N}$ & 75 & 75 & 75 & 75 & 75 & 75 \\
\hline
\end{tabular}

Source: Processed Primary Data

Table 1.2. Result of VIF Test

\begin{tabular}{|c|c|c|c|c|c|c|c|c|}
\hline \multicolumn{2}{|r|}{ Model } & \multicolumn{2}{|c|}{$\begin{array}{l}\text { Unstandardized } \\
\text { Coefficients }\end{array}$} & \multirow{2}{*}{$\begin{array}{c}\begin{array}{c}\text { Standardized } \\
\text { Coefficients }\end{array} \\
\text { Beta }\end{array}$} & \multirow[t]{2}{*}{$\mathrm{t}$} & \multirow[t]{2}{*}{ Sig. } & \multicolumn{2}{|c|}{ Collinearity Statistics } \\
\hline & & $\mathrm{B}$ & Std. Error & & & & Tolerance & VIF \\
\hline \multirow[t]{6}{*}{1} & [Constant] & .210 & 1.150 & & .183 & .855 & & \\
\hline & Flood Risk [X1] & -.183 & .409 & -.055 & -.447 & .656 & .849 & 1.178 \\
\hline & Health Facilities [X2] & .213 & .423 & .061 & .504 & .616 & .862 & 1.159 \\
\hline & Age [X3] & $-1.141 \mathrm{E}-7$ & .000 & -.036 & -.311 & .757 & .950 & 1.053 \\
\hline & $\begin{array}{l}\text { Precentage of } \\
\text { Settlement Area [X } 4]\end{array}$ & $3.163 \mathrm{E}-7$ & .000 & .095 & .788 & .434 & .879 & 1.138 \\
\hline & $\begin{array}{l}\text { Precentage of Paddy } \\
\text { Field [X5] }\end{array}$ & $1.651 \mathrm{E}-6$ & .000 & .326 & 2.766 & .007 & .914 & 1.094 \\
\hline
\end{tabular}

Source: Processed Primary Data 
Indonesian Journal of Geography, Vol 48, No. 2, December 2016 : 168 - 177

Table 1.3. Number of AIC and R2 Semiparametric Regression Model according to Kernel Function

\begin{tabular}{lcccc}
\hline \multicolumn{1}{c}{ Type of Weighting Funciton } & Local & Global & AIC & $\mathrm{R}^{2}$ \\
\hline Fixed Gaussian & $\mathrm{X} 1, \mathrm{X} 2, \mathrm{X} 3, \mathrm{X} 4$ & $\mathrm{X} 5$ & 371,41 & 8,68 \\
Fixed Bisquare & $\mathrm{X} 1, \mathrm{X} 2, \mathrm{X} 3, \mathrm{X} 4$ & $\mathrm{X} 5$ & 367,10 & 8,51 \\
Adaptive Bisquare & $\mathrm{X} 1, \mathrm{X} 2, \mathrm{X} 3, \mathrm{X} 4$ & $\mathrm{X} 5$ & 377,23 & 9,6 \\
Adaptive Gaussian & $\mathrm{X} 1, \mathrm{X} 2, \mathrm{X} 3, \mathrm{X} 4$ & $\mathrm{X} 5$ & 384,76 & 9,3 \\
\hline
\end{tabular}

Table 1.4. Weight of Parameters

\begin{tabular}{llrrrr}
\hline \multicolumn{1}{c}{ Village } & \multicolumn{5}{c}{ Weight } \\
\cline { 2 - 6 } & $\mathrm{X} 1$ & $\mathrm{X} 2$ & \multicolumn{1}{c}{$\mathrm{X} 3$} & \multicolumn{1}{c}{$\mathrm{X} 4$} & \multicolumn{1}{c}{$\mathrm{X} 5$} \\
\hline Ngestiharjo & 2,658626 & 0,762708 & $-0,076463$ & 1,28845 & 0,502781 \\
Baturetno & 0,826364 & 0,764179 & $-0,171975$ & $-0,586911$ & 0,467826 \\
Argomulyo & 5,981403 & $-0,836777$ & $-1,928035$ & $-1,785132$ & $-1,646096$ \\
Banguntapan & 0,928812 & 0,715903 & $-0,166384$ & $-0,502819$ & 0,523443 \\
Argosari & 2,258967 & 1,031255 & $-3,681269$ & $-3,578291$ & 2,036242 \\
Tamantirto & 4,668735 & 0,010576 & $-0,15111$ & 0,944663 & 0,063049 \\
Argorejo & 6,118368 & $-0,407586$ & $-2,153503$ & $-2,525646$ & $-1,026328$ \\
Tirtonirmolo & 4,373727 & 0,825374 & 0,240844 & 1,632985 & 0,438737 \\
Bangunjiwo & 5,362278 & $-0,728622$ & 0,511432 & 0,043021 & $-0,39379$ \\
Srimulyo & 1,496677 & 0,521447 & $-0,687029$ & $-0,441661$ & 1,111446 \\
Argodadi & 2,712929 & 1,684879 & $-3,674974$ & $-4,721193$ & 2,396848 \\
Srimartani & 0,166561 & 0,24774 & 0,063634 & $-0,38246$ & 0,020266 \\
Sitimulyo & 2,988197 & 0,759593 & $-1,025188$ & $-0,480185$ & 2,069999 \\
Potorono & 3,239817 & 0,698899 & $-0,981772$ & $-0,564376$ & 2,048535 \\
Bangunharjo & 5,389499 & 0,022164 & 0,589698 & 0,499595 & 0,454835 \\
Panggungharjo & 5,290806 & 0,347141 & 0,52914 & 1,120515 & 0,219708 \\
Jagalan & 2,897269 & 0,657822 & 0,051031 & $-0,508902$ & 1,211943 \\
Tamanan & 4,739982 & 0,172823 & 0,351 & $-0,125823$ & 1,21367 \\
Singosaren & 3,767295 & 0,475047 & $-0,524688$ & $-0,468981$ & 1,90137 \\
Triwidadi & 5,519227 & $-1,849498$ & 0,530843 & $-1,590033$ & $-1,1566$ \\
Jambidan & 4,849799 & 0,574733 & $-1,331879$ & $-0,398087$ & 2,871914 \\
Wirokerten & 5,627894 & 0,08103 & $-0,692344$ & $-0,210092$ & 2,61106 \\
\hline
\end{tabular}

\begin{tabular}{llrrrr}
\hline \multirow{1}{*}{ Village } & \multicolumn{5}{c}{ Weight } \\
\cline { 2 - 6 } & \multicolumn{1}{c}{ X1 } & \multicolumn{1}{c}{ X2 } & \multicolumn{1}{c}{ X3 } & \multicolumn{1}{c}{ X5 } \\
\hline Pendowoharjo & 6,701897 & $-0,319505$ & 0,937645 & 0,929812 & $-0,379164$ \\
Sendangsari & 4,271805 & $-0,771069$ & 1,701274 & $-0,304373$ & $-0,369615$ \\
Guwosari & 5,560985 & $-0,91427$ & 1,649489 & 0,001439 & $-0,61558$ \\
Wonokromo & 7,490807 & $-0,586005$ & $-0,151434$ & 0,316868 & 2,232582 \\
Pleret & 6,549043 & $-0,007961$ & $-1,142684$ & $-0,022931$ & 3,060206 \\
Timbulharjo & 8,311913 & $-1,036685$ & 0,511193 & 1,19291 & 0,262367 \\
Bantul & 7,363351 & $-0,856432$ & 1,605083 & 0,509643 & $-1,136366$ \\
Bawuran & 5,243826 & 0,301115 & $-1,281351$ & $-0,094095$ & 2,703933 \\
Terong & 1,838703 & 0,439541 & $-0,718445$ & $-0,103931$ & 1,447004 \\
Wonolelo & 3,949173 & 0,263038 & $-1,203695$ & 0,002596 & 2,215114 \\
\hline
\end{tabular}




\begin{tabular}{|c|c|c|c|c|c|}
\hline \multicolumn{4}{|c|}{ Application of Geographically Weighted Regression } & \multicolumn{2}{|c|}{ Prima Widayani., et., all } \\
\hline Trimulyo & 9,016281 & $-1,244342$ & $-0,433353$ & 1,04821 & 2,511889 \\
\hline Segoroyoso & 7,037343 & $-0,313865$ & $-1,031498$ & 0,208301 & 2,748766 \\
\hline Ringinharjo & 6,536347 & $-0,607485$ & 1,891848 & 0,33642 & $-1,122652$ \\
\hline Trirenggo & 8,608045 & $-1,147451$ & 1,558065 & 1,02387 & $-1,283536$ \\
\hline Sabdodadi & 9,342147 & $-1,482528$ & 0,915832 & 1,406815 & $-0,314018$ \\
\hline Muntuk & 3,331194 & $-0,615439$ & $-1,003995$ & 0,293989 & 1,424369 \\
\hline Jatimulyo & 0,710736 & 0,133466 & $-0,153304$ & 0,010169 & 0,623901 \\
\hline Gilangharjo & 4,664222 & 0,707325 & 2,150141 & 0,437747 & $-0,7786$ \\
\hline Wijirejo & 4,327958 & 0,403038 & 2,137598 & 0,260397 & $-0,264362$ \\
\hline Wukirsari & 7,410061 & $-1,123374$ & $-1,100075$ & 0,989121 & 2,053827 \\
\hline Palbapang & 7,110356 & $-0,38957$ & 2,039053 & 0,675652 & $-1,664991$ \\
\hline Patalan & 8,185152 & $-1,166979$ & 1,750323 & 1,508436 & $-0,863021$ \\
\hline Temuwuh & 1,759971 & $-0,137409$ & $-0,411796$ & 0,107429 & 0,986501 \\
\hline Imogiri & 8,841978 & $-1,52474$ & $-0,502589$ & 2,112804 & 1,884935 \\
\hline Triharjo & 2,73169 & 1,124753 & 2,086437 & 0,241916 & 0,29518 \\
\hline Canden & 8,490867 & $-1,43289$ & 1,201111 & 1,88814 & 0,354179 \\
\hline Girirejo & 7,819908 & $-1,495138$ & $-1,186291$ & 2,24762 & 1,687638 \\
\hline Sumbermulyo & 6,314597 & $-0,114144$ & 2,080078 & 0,838659 & $-1,73329$ \\
\hline Mangunan & 5,674722 & $-2,486972$ & $-1,226355$ & 2,147951 & 0,478907 \\
\hline Karangtalun & 8,714912 & $-1,491648$ & $-0,127463$ & 2,220015 & 1,53681 \\
\hline Kebon Agung & 8,083562 & $-1,444803$ & 0,437729 & 2,125002 & 1,090408 \\
\hline Trimurti & 1,026299 & 0,571023 & $-0,028481$ & $-0,154984$ & 0,366974 \\
\hline Caturharjo & 1,397568 & 1,176482 & 0,864307 & 0,061333 & 0,05397 \\
\hline Dlingo & 4,382543 & $-0,575536$ & 0,021009 & 1,871377 & $-0,009897$ \\
\hline Karang Tengah & 7,568279 & $-1,544209$ & $-0,654792$ & 2,243102 & 1,355083 \\
\hline Mulyodadi & 4,000312 & 0,557286 & 1,622975 & 0,609312 & $-1,50611$ \\
\hline Sriharjo & 7,098925 & $-1,756646$ & $-0,632273$ & 2,10906 & 1,156843 \\
\hline Srihardono & 5,589865 & $-1,127556$ & 1,561085 & 1,576113 & $-0,406007$ \\
\hline Sidomulyo & 1,823752 & 1,323328 & 0,97093 & 0,289025 & $-0,855305$ \\
\hline Selopamioro & 5,866076 & $-2,38$ & $-0,259669$ & 1,595989 & 0,574599 \\
\hline Panjangrejo & 3,034301 & $-0,153884$ & 1,045446 & 0,81446 & $-1,085076$ \\
\hline Poncosari & 0,558357 & 0,276715 & $-0,275557$ & $-0,350587$ & 0,047854 \\
\hline Gadingsari & 0,536991 & 0,507021 & $-0,255209$ & $-0,287594$ & $-0,085118$ \\
\hline Murtigading & 0,590813 & 0,916236 & $-0,115269$ & $-0,153239$ & $-0,227425$ \\
\hline \multirow[t]{2}{*}{ Village } & \multicolumn{5}{|c|}{ Weight } \\
\hline & $\mathrm{X} 1$ & $\mathrm{X} 2$ & $\mathrm{X} 3$ & $\mathrm{X} 4$ & $\mathrm{X} 5$ \\
\hline Tirtomulyo & 0,66527 & 1,391524 & 0,252761 & 0,106046 & $-0,602959$ \\
\hline Seloharjo & 2,581881 & $-0,751179$ & 0,659115 & 0,690009 & $-0,302931$ \\
\hline Srigading & 0,485761 & 0,798863 & $-0,173808$ & $-0,205214$ & $-0,210705$ \\
\hline Donotirto & 0,899929 & 0,980123 & 0,188091 & 0,113218 & $-0,669766$ \\
\hline Gadingharjo & 0,508446 & 0,676893 & $-0,212839$ & $-0,249521$ & $-0,154648$ \\
\hline Tirtosari & 0,443971 & 1,160326 & $-0,03556$ & $-0,053217$ & $-0,459552$ \\
\hline Parangtritis & 0,365893 & 0,720849 & $-0,091189$ & $-0,13174$ & $-0,117021$ \\
\hline Tirtohargo & 0,458671 & 0,76932 & $-0,167617$ & $-0,235259$ & $-0,180398$ \\
\hline
\end{tabular}


Figure 1.2. are map of the percentage of residential land (a) and percentage of paddy field area (b). Those map obtained from the interpretation of ALOS. Figure 1.3. are flood risk map (a), the percentage of the population's age (b) and the number of health facilities (c) which obtained from secondary data

Figure 1.3. Show Vulnerability map of Leptospirosis in Batul District. There are 3 vulnerable area of Leptospirosis disease, high vulnerability area located in the middle of Bantul
District, meanwhile the medium and low vulnerability area showed clustered pattern in the side of Bantul District.

Figure 1.4. Show Vulnerability map of Leptospirosis in Batul District. There are 3 vulnerable area of Leptospirosis disease, high vulnerability area located in the middle of Bantul

District, meanwhile the medium and low vulnerability area showed clustered pattern in the side of Bantul District.

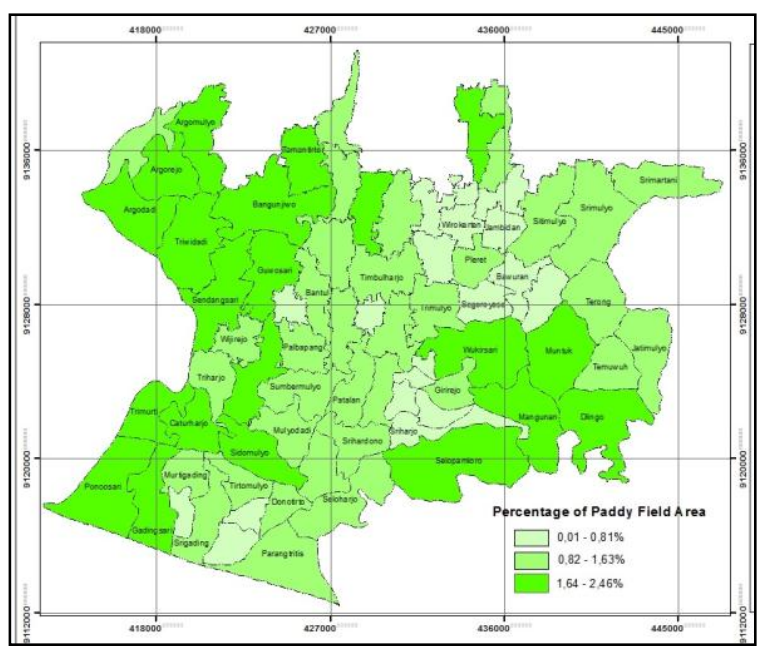

(a)

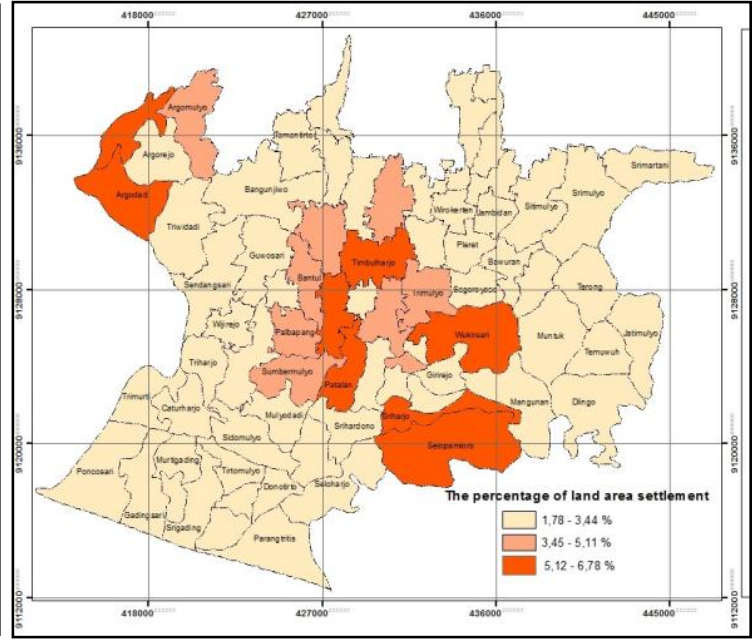

(b)

Figure 1.2. are map of the percentage of residential land (a) and percentage of paddy field area (b).

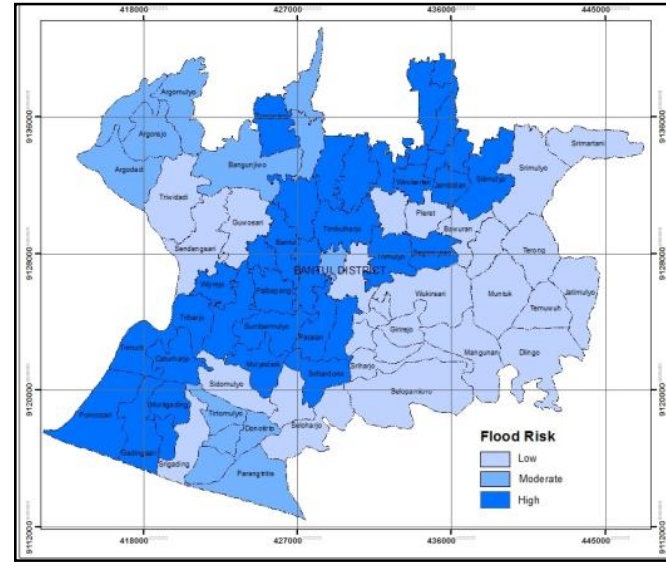

(a)

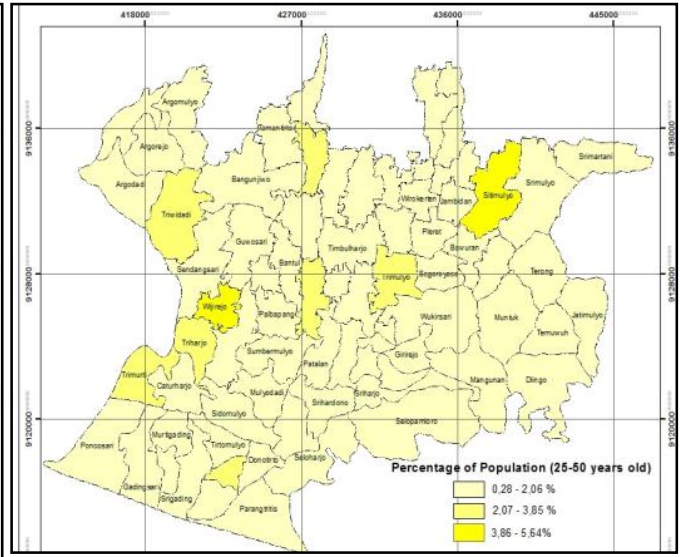

(b) 


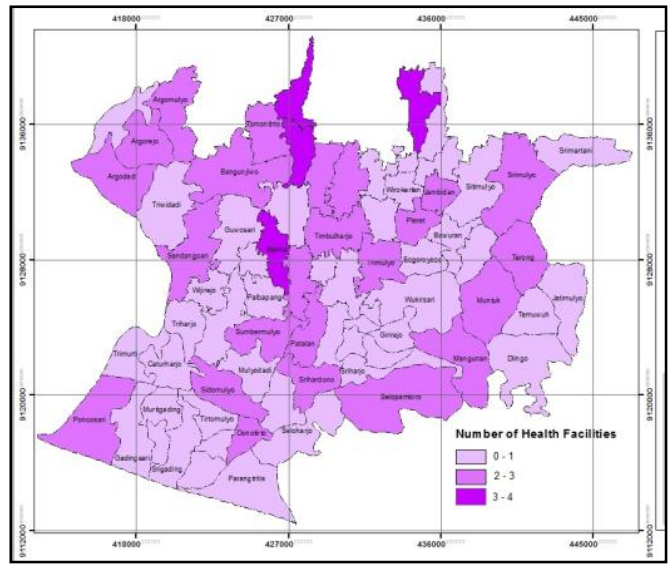

(c)

Figure1.3. are flood risk map (a), the percentage of the population's age (b), and the number of health facilities (c)

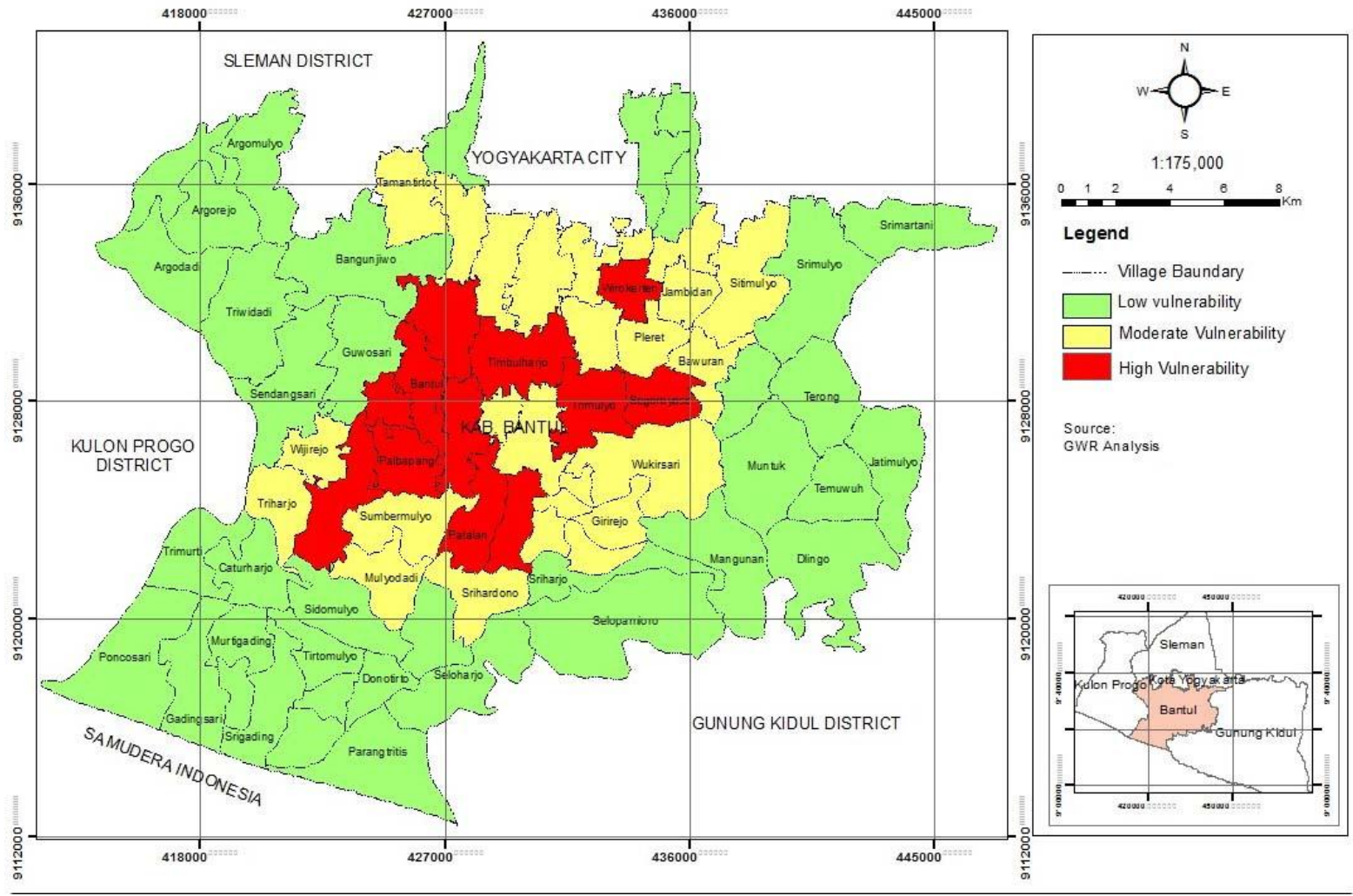

Figure 1.4. Vulnerability map of Leptospirosis in Batul District

\section{Conclusion}

The best region vulnerability modeling of Leptospirosis resulted by type of weighting funcition Fixed Bisquare that showed by the lowest number of AIC : 367,10 . Independent variables that affect locally : Flood Risk (X1), Health Facilities (X2), Percentage of Age 25-50 years old (X3),
Percentage of Settlement Area (X4). In other hand, percentage of Paddy Field affect globally. Vulnerability Area Mapping of Leptospirosis resulted from GWR is using Fixed Bisquare because of the lowest number of AIC. There are three levels of vulnerabilty in Bantul Regency. High vulnerable level located in the middle of Bantul Regency like 
Bantul District, Sewon District, and Jetis District. Meanwhile moderate and low vulnerable level indicates clustered patterns on the outskirts of Bantul Regency.

\section{Recommendation}

It is better if add some others independent variables like percentage of population jobs and enviromental sanitation condition so that modelling will result more complete and detail information.

\section{References}

Chiara Bocci, Alessandra Petrucci and Emilia Rocco. (2000). An application of Geographically Weighted Regression to Agricultural Data for SmallArea Estimates Dipartimento di Statistica “G. Parenti”. Universit'a degli Studi di Firenze, viale Morgagni, 59 - 50134 Firenze, Italy.

Dwi Sarwani. (2005). Environmental Risk Factor of Leptospirosis in Semarang City. Tesis. Diponegoro University.

Bantul Public Health Service, (2010). Surveilans Leptospirosis Data 2010. Bantul.

Fotheringham. (2002). Geographically Weighted Regression: The Ananlysis of Spatially Varying Relationships. UK.

Harini, R.,Susilo, B.,Nurjani, E.,(2015).Geographic Information System-Based Spatial Analysis of Agricultural Land Suitability in Yogyakarta. Indonesian Journal of Geography. Vol. 47, No.2, December 2015 (171 - 179).

Ima Nurisa. (2005). Penyakit Bersumber Rodensia ( Tikus dan Mencit) di Indonesia dalam. Jurnal Ekologi Kesehatan. 4 (3), 308 - 319.

Nakaya Tomok. (2009). GWR User Manual. Department of Geography, Ritsumeikan University.

NSDA. (2009). ALOS Spesification. LAPAN.
Pavel Propastin, Martin Kappas and Stefan Erasmi. (2007). Application of Geographically Weighted Regression to Investigate the Impact of Scale on Prediction Uncertainty by Modelling Relationship between Vegetation and Climate. International. Journal of Spatial Data Infrastructures Research. 3, 73-94.

Pfeiffer, Robinson, Stevenson, and Stevent. (2008). Spatial Analysis in Epidemiology. Oxford University Press.

Priyanto. (2008). Risk Factors of Leptospirosis ( Case Study in Demak District). Article Post Graduate Program. Diponegoro University.

Riyaningsih, Suharyo Hadisaputro, and Suhartono. (2010). Enivironmental Risk Factors That Influence The Incidence of Leptospirosis in Central Java (Case Study in The City of Semarang, Demak Regency and Paty). Jurnal Kesehatan Lingkungan Indonesia. 11 (1) / April 2012.

WHO. (2003). Leptospirosis. World Health Organization. http://www.who.int/en/ (downloaded 2 December 2014)

Yoeniarti Shara, Henny Pramoedyo, and Maria Bernadetha Mitakda. (2008). Geographically Weighted Regression Modeling Used Fixed Bisquare Kernel for Spatial Data (Case Study: Malnutrition in West Java Province).Brawijaya University. 